\title{
Simulation of Spinneret Micro-hole Spade Drill Drilling Based on DEFORM-3D
}

Zhang Chunyan ${ }^{1,2}$, Yang Chongchang ${ }^{2}$, Zhang Ronggen ${ }^{2}$

${ }^{1}$ Shanghai University of Engineering Science, 333 Longteng Road, Shanghai 201620, China

2Donghua University, 1882 Yan'an Road West, Shanghai, China, 200051, E-mail: ycc@dhu.edu.cn

An emulation study of the drilling by the spade drill on the spinneret micro-hole is conducted by using FEM analysis software Deform-3D. According to application of finite element software Deform-3D, some characteristic parameter of the work piece and the cutting tool material are set. The distributed situation of cutting force, cutting temperature and tool wear in different cutting parameters are simulated analysis. By discussing the location of the spade drill drilling wear, further optimization of parameters cutting and tool for the spinneret micro-hole drilling provide the better basis.

Keywords: Deform-3D, Spade Drill, Spinneret Micro-hole, Cutting force, cutting temperature, Tool wear

\section{References}

[1] WANG, Y., SHI, C., CUI, Z. (2006). Design of spinneret [J]. Polyester Industry, 2006, 19(3):27-30.

[2] PENG, H., YUAN, F. (2010). Experiments and analysis of the near-dry deep hole drilling system [J]. Modern manufacturing engineering, 2010(04):79-81

[3] ZHANG, Z., ZHANG, J., WANG, L. (2011). FEA of Cutting Force of Stainless Steel Based on DEFORM-3D [J]. Light Industry Machinery, 2011, 29(4):40-42

[4] PUJANA, J., RIVERO, A., CELAYA, A., et al. (2009). Analysis of ultrasonic-assisted drilling of Ti6A14V [J] International Journal of Machine Tools\& Manufacture, 2009 (49).

[5] YANG, J., ZHOU, L., WU, N. (2007). Simulation of Drilling Force Based on Software Deform 3D [J]. Tool Engineering. 2007, 41(04)50-53

[6] GUO, L., YANG, CH., DAI, H, et al. (2008). Machining Technology of Large Lenth-diameter Ratio Pilot Microhole of Spinneret. Tool Engineering. 2008,42(01)97-99

[7] GAO, B. (2013). Research on Spinneret of Bottom Hole Automatic Processing. [D] Dong hua University, 2013

[8] YANG, CH. (2008). Studies on Design, Manufacture and Applications of Spinneret for Melt-spinning Shaped Fibers. [D]. Dong hua University, 2008

[9] YING, Z., ZHOU, L., WANG, J., LIU, L. (2011). FEM Dynamic Simulation of Drill with Indexable Inserts. [J] Tool Engineering. 2011(10):20-23.

[10] LI, CH., WANG, X., YAN, H. (2006). DEFORM5.03 Metal Forming Finite Element Analysis. [M].Beijing, CHINA MACHINE PRESS, 2006

[11] GAO, X., LI, P., YAN, P., ZOU, P. (2011). Simulation of Stainless Steel Drilling Mechanism Based on Deform3D [J]. Tool Engineering. 2011(4):17-20.

[12] KYNCL, L., SADÍlEK, M., ČEP, R., PETRŮ, J., STANCEKOVA, D., PROCHÁZKA, P., NOVÁČEK, P. (2015). Tests of Drills during Drilling Holes into Alloy Wheels [J]. Manufacturing Technology. 2015,14(4): 554556

[13] MAŇKOVÁ, I., VRABEL', M., BEŇO, J., KOVAC, P., GOSTIMIROVIC, M. (2013). Application of Taguchi Method and Surface Response Methodology to Evaluate Of Mathematical Models to Chip Deformation when Drilling With Coated and Uncoated Twist Drills. [J]. Manufacturing Technology. 2013, 13(4): 492-499

[14] MENG, L. N., WANG, A. H., WU, YU, WANG, XI; XIA, H.B.; WANG, Y.N. (2015). Blind micro-hole array Ti6Al4V templates for carrying biomaterials fabricated by fiber laser drilling [J].Journal of Materials Processing Technology, 2015, 222: 335-343.

[15] FURUTANI, KATSUSHI .HIRAOKA, DAISUKE. (2014). Condition monitoring in concurrent micro-hole electrical discharge machining with electrode feeding devices employing AZARASHI (Seal) mechanism Procedia CIRP, 2014,14: 424-429

[16] ADELMANN, B, HELLMANN, R. (2015). Rapid micro hole laser drilling in ceramic substrates using single mode fiber laser [J]. Journal of Materials Processing Technology, 2015, 221 : 80-86 
[17] DAS, AK, SAHA, P. (2015). Experimental investigation on micro-electrochemical sinking operation for fabrication of micro-holes [J].Journal of the Brazilian of society of mechanical sciences and engineering, 2015,37:657663

[18] PATWA, R., HERFURTH, H., BRATT, C., Laser drilling of micro-hole arrays in tantalum [J]. Journal of laser applications, 2015,27(2)

[19] HA, K.H., LEE, S.W., KIM, J., JEE, W.Y., CHU, C.N. (2015).Fabrication of a micro-hole array on metal foil by nanosecond pulsed laser beam machining using a cover plate [J].Journal of micromechanics and microengineering, 2015, 25:2

[20] VAZQUEZ, E., GOMAR, J., CIURANA, J., RODRIGUEZ, C.A. (2015). Evaluation of machine-tool motion accuracy using a CNC machining center in micro-milling processes[J]. International journal of advanced manufacturing technology, 2015,76:219-228

[21] RAHAMATHULLAH, I., SHUNMUGAM, M.S. (2015). Mechanistic approach for prediction of forces in microdrilling of plain and glass-reinforced epoxy sheets[J].2015, 75(5): 1177-1187

\section{Paper number: M2016235}

Copyright $($ 2016. Published by Manufacturing Technology. All rights reserved. 